\title{
Effect of Dissolved Oxygen and Immersion Time on the Corrosion Behaviour of Mild Steel in Bicarbonate/Chloride Solution
}

\author{
Gaius Debi Eyu *, Geoffrey Will, Willem Dekkers and Jennifer MacLeod \\ Department of Chemistry, Physics and Mechanical Engineering, Queensland University of Technology, \\ Brisbane QLD 4000, Australia; g.will@qut.edu.au (G.W.); w.dekkers@qut.edu.au (W.D.); \\ jennifer.macleod@qut.edu.au (J.M.) \\ * Correspondence: gaius.eyu@qut.edu.au; Tel.: +61-24429877 \\ Academic Editor: Richard Thackray \\ Received: 4 August 2016; Accepted: 22 August 2016; Published: 1 September 2016
}

\begin{abstract}
The electrochemical behavior of mild steel in bicarbonate solution at different dissolved oxygen (DO) concentrations and immersion times has been studied under dynamic conditions using electrochemical techniques. The results show that both DO and immersion times influence the morphology of the corrosion products. In comparative tests, the corrosion rate was systematically found to be lower in solutions with lower $\mathrm{DO}$, lower $\mathrm{HCO}_{3}{ }^{-}$concentrations and longer immersion time. The SEM analyses reveal that the iron dissolution rate was more severe in solutions containing higher DO. The decrease in corrosion rate can be attributed to the formation of a passive layer containing mainly $\alpha$-FeO $(\mathrm{OH})$ and $\left(\gamma-\mathrm{Fe}_{2} \mathrm{O}_{3} / \mathrm{Fe}_{3} \mathrm{O}_{4}\right)$ as confirmed by the X-ray diffractometry (XRD) and $\mathrm{X}$-ray photoelectron spectroscopy (XPS). Passivation of mild steel is evident in electrochemical test at $\approx-600 \mathrm{mV}_{\mathrm{SCE}}$ at $\mathrm{pH} \geq 8$ in dearated ( $\leq 0.8 \mathrm{ppm} \mathrm{DO}$ ) chloride bicarbonate solution under dynamic conditions.
\end{abstract}

Keywords: mild steel; bicarbonate; polarization; passivation

\section{Introduction}

Bicarbonate plays a major role in the dissolution reactions of steel pipelines [1]. Studies indicate that increasing $\mathrm{HCO}_{3}{ }^{-}$concentration exacerbates iron dissolution [2-4]. To date, the role of bicarbonate ions in the corrosion process of carbon steel is still debated [5] Moreno et al. [6] confirmed that high bicarbonate increased localized corrosion contributing to stress corrosion cracking $[7,8]$ and pitting corrosion [9] in carbon steel pipelines. Thomas and Davies [10] reported that bicarbonate ions reduce the passive-active (Flade) potential for ferric oxides, while increasing the passive-active transition potential for magnetite with increasing $\mathrm{HCO}_{3}{ }^{-}$concentration when the concentration is greater than $10^{-2} \mathrm{M}$. However, some researchers argued that a stable-film formation (passivity) can be achieved when a sufficient amount of bicarbonate is present [11-13]. The formation and stability of such passive films depends to a large extent on environmental conditions, such as; applied potential, $\mathrm{pH}$, oxygen, solution chemistry, temperature, fluid flow rate, immersion time and metallurgy of the steel [14-16]. Bicarbonate-induced corrosion is potentially relevant in many applications, such as wellbore systems for geological sequestration of $\mathrm{CO}_{2}$ [17]. Intergranular stress corrosion cracking (IGSCC) in underground pipelines at potential range $\left(\approx-0.625 \mathrm{~V}_{\mathrm{SCE}}\right.$ to $\left.\approx-0.425 \mathrm{~V}_{\mathrm{SCE}}\right)$ has been linked with the presence $\mathrm{HCO}^{-}$and $\mathrm{CO}_{3}{ }^{2-}$ ions at $\mathrm{pH}(8-10.5)$ [18]. Delanty and O'Beirne [19] cited a Canadian investigation that revealed that stress corrosion cracking (SCC) in carbon steel X65 was more severe in oxygen restricted areas, presumably because oxygen reduction prevents hydrogen evolution which is thought to facilitate cracking. In contrast, Yunovich et al. reported that SCC susceptibility of API X52 carbon steel was higher in an aerated conditions than in deaerated solution 
at $\mathrm{pH} 8$ and 10 [18]. Dissolved oxygen has been shown to increase corrosion rates [20-24] as expected however, Beckett et al. and Sarin et al. $[25,26]$ claimed it decreased with higher DO under stagnant conditions. Dissolved oxygen is an electron acceptor in the corrosion of iron as well as oxidation of ferrous iron [27]:

$$
\begin{gathered}
\mathrm{Fe}+1 / 2 \mathrm{O}_{2}+\mathrm{H}_{2} \mathrm{O} \leftrightarrow \mathrm{Fe}^{2+}+2 \mathrm{OH}^{-} \\
\mathrm{Fe}^{2+}+1 / 4 \mathrm{O}_{2}+1 / 2 \mathrm{H}_{2} \mathrm{O}+2 \mathrm{OH}^{-} \leftrightarrow \mathrm{Fe}(\mathrm{OH})_{3(\mathrm{~s})}
\end{gathered}
$$

Kuch [28] reported that in the absence of oxygen, it is possible for ferric scale $\gamma$-FeOOH (lepidocrosite) previously formed on the metal surface to act as an electron acceptor:

$$
\mathrm{Fe}+2 \mathrm{FeOOH}_{(\text {scale })}+2 \mathrm{H}^{+} \leftrightarrow 3 \mathrm{Fe}^{2+}+4 \mathrm{OH}
$$

The corrosion process continues even after DO is depleted according to the Kuch mechanism. However, in the absence of lepidocrosite in the scale, the corrosion reaction still proceeds in deaerated water as reported elsewhere [26], indicating that in a near-neutral $\mathrm{pH}$ environment, the Kuch mechanism is not the only mechanism of metal loss in deaerated conditions. Baek et al. [29] concluded that $\mathrm{DO}$ facilitates the formation of different iron oxide products. For example, $\mathrm{FeOOH}$ and $\gamma-\mathrm{Fe}_{2} \mathrm{O}_{3}$ were formed at high DO concentrations whereas $\alpha-\mathrm{Fe}_{2} \mathrm{O}_{3}$ was formed in deaerated solution at a more positive potential. The influence of dissolved oxygen and immersion time in the corrosion process of mild steel in a near-neutral $\mathrm{pH}$ in corrosive media remains controversial. Here, we present an investigation of the corrosion behaviour of mild steel in chloride-containing bicarbonate solutions of varied $\mathrm{DO}$ and immersion time in near-neutral $\mathrm{pH}$, under dynamic conditions at moderate temperature $\left(23 \pm 1^{\circ} \mathrm{C}\right)$. Potentiodynamic polarization and electrochemical impedance spectroscopy were used to study the corrosion processes for the electrochemical tests. By incorporating a range of surface analysis techniques, including X-ray diffraction (XRD) and scanning electron microscopy (SEM), we were able to characterize the chemistry and morphology of the corrosion products.

\section{Results and Discussion}

\subsection{Bicarbonate Concentration}

Figure 1 shows the polarization profile for mild steel in $1 \mathrm{~g} / \mathrm{L}$ and $5 \mathrm{~g} / \mathrm{L}$ bicarbonate with $2 \mathrm{~g} / \mathrm{L}$ chloride concentration under dynamic conditions. Bicarbonate has a distinct effect on the polarization characteristics in bicarbonate/chloride solution. The dissolution in the active and prepassive region is accelerated by the presence of bicarbonate ions due to the formation of soluble complex anion $\mathrm{Fe}\left(\mathrm{CO}_{3}\right)_{2}{ }^{2-}$ [3]. At $\approx-600 \mathrm{mV}_{\mathrm{SCE}}, \mathrm{Fe}(\mathrm{OH})_{2}$ is converted to $\mathrm{Fe}_{3} \mathrm{O}_{4}[29]$ in dearated bicarbonate solution, resulting in passivation. At this potential $\left(\approx-600 \mathrm{mV}_{\mathrm{SCE}}\right), \mathrm{Fe}_{2} \mathrm{O}_{3} / \mathrm{Fe}_{3} \mathrm{O}_{4}$ forms an oxide film at $\mathrm{pH} \geq 8$. The anodic polarization current was greater with $5 \mathrm{~g} / \mathrm{L}$ bicarbonate solution at corrosion potential $\approx-600 \mathrm{mV}_{\mathrm{SCE}}$. However, above this potential, the dissolution decreased with increasing bicarbonate concentration.

The impedance spectra were obtained from a rotating disc electrode (specimen) immersed in solutions containing $1 \mathrm{~g} / \mathrm{L}$ and $5 \mathrm{~g} / \mathrm{L}$ bicarbonate in chhloride solution. The data was fit with equivalent circuit shown in Figure 2, and shows a good fit to the data and represents the physical situation expected [30,31], where $R_{s}, R_{c t}, R_{a}, Q_{d l}$ and $Q_{f}$ represent the solution resistance, charge transfer resistance (metal/film interface), adsorption resistance (solution/film interface), double layer capacitance and passive film capacitance, respectively. A constant phase element (CPE) defined by the values of $\mathrm{n}$ and $\mathrm{Q}$, is commonly used to compensate for inhomogeneity of electrode surface. The impedance $Z$, of the constance phase element as given in [32]:

$$
\mathrm{Z}_{\mathrm{CPE}}=\mathrm{Q}^{-1}(\mathrm{j} \omega)^{-\mathrm{n}},
$$


where $\mathrm{Q}$ and $\mathrm{n}$ are constant and exponent, respectively, $\mathrm{j}=(\sqrt{-1})$ and $\omega=2 \pi f$ is the angular frequency in $\mathrm{rad} / \mathrm{s}$ calculated using $f$, the frequency in $\mathrm{H}_{\mathrm{z}}$. At low frequency, the impedance and phase angle describe the kinetic response for the charge transfer activity, while at high frequency they depend on surface layer inhomogeneity [33].

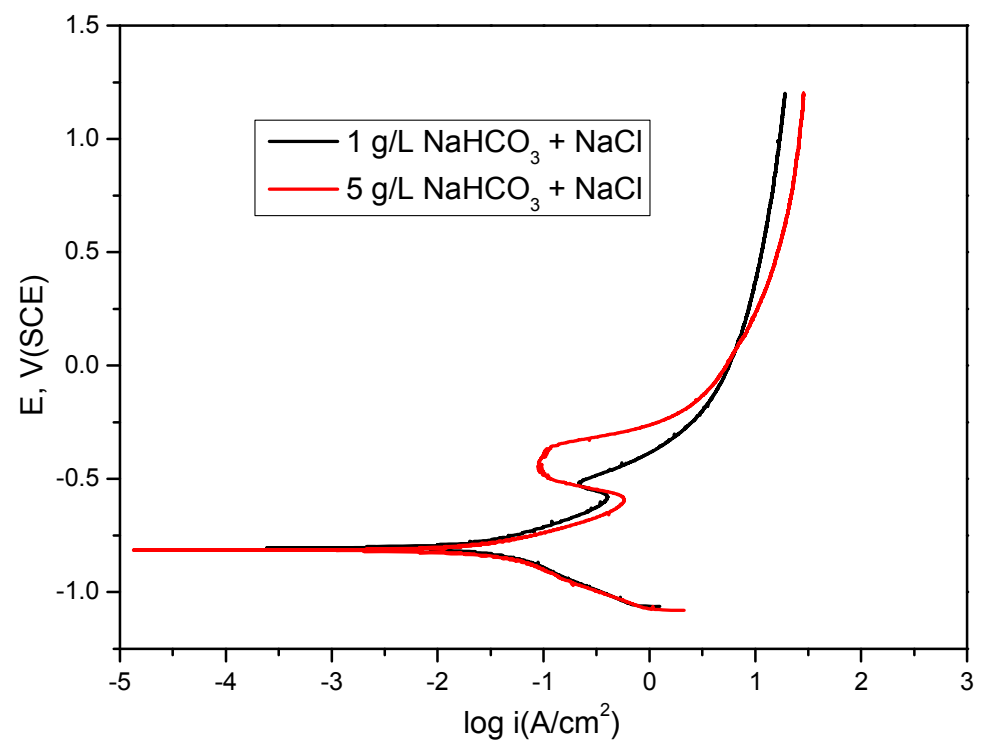

Figure 1. Potentiodynamic polarization for mild steel in $1 \mathrm{~g} / \mathrm{L}$ and $5 \mathrm{~g} / \mathrm{L}$ bicarbonate/chloride solutions at $2000 \mathrm{rpm}$.

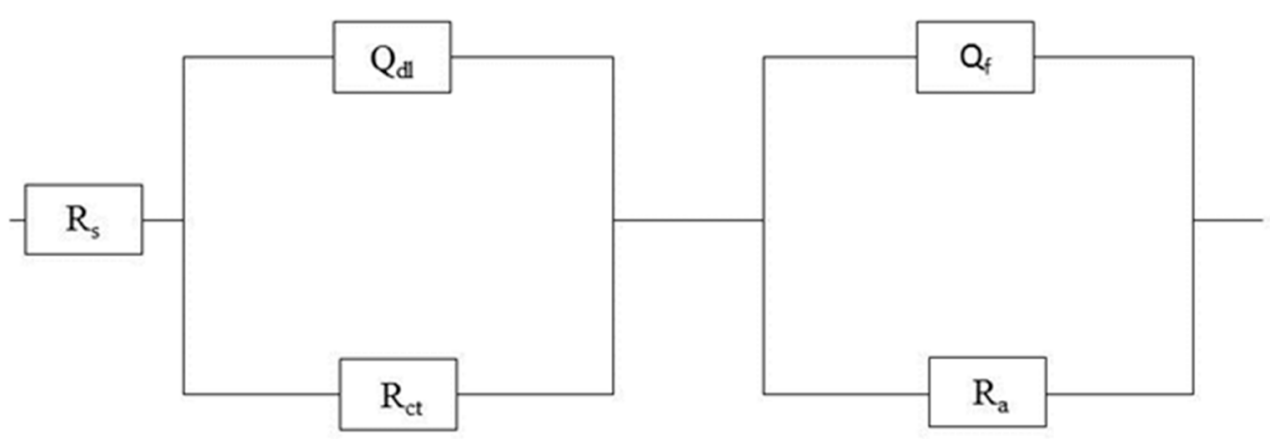

Figure 2. Equivalent circuit for impedance measurements.

Figure 3a,b show the Nyquist and Bode-phase plots measured for specimens in $1 \mathrm{~g} / \mathrm{L}$ and $5 \mathrm{~g} / \mathrm{L}$ bicarbonate/ chloride solutions. The impedance spectra show similar trends, although the capacitive loop was depressed with higher bicarbonate concentration. The decrease in the impedance spectra is linked to iron dissolution which contributes to uneven surface roughness and irregular distribution of current density on the specimen surface. The Bode impedance plots in Figure $3 \mathrm{~b}$ show that at low frequencies, the impedance is slightly lower with higher bicarbonate concentration. The lower bicarbonate concentration exhibits higher impedance in the capacitive region, which implies that a more protective oxide layer is achieved in low concentration bicarbonate. For this lower concentration solution, the phase angle $(\theta)$ is higher at low frequencies compared to solution with higher bicarbonate, indicating a more resistive barrier film layer at lower concentration. The cross-sections of the corrosion products shown in Figure 4 reveal that a more uniform corrosion product was formed in $1 \mathrm{~g} / \mathrm{L}$ bicarbonate in comparison with $5 \mathrm{~g} / \mathrm{L}$ bicarbonate solution. 


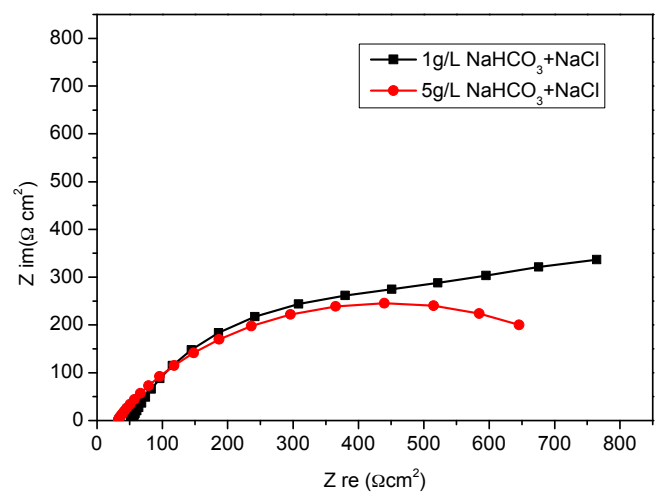

(a)

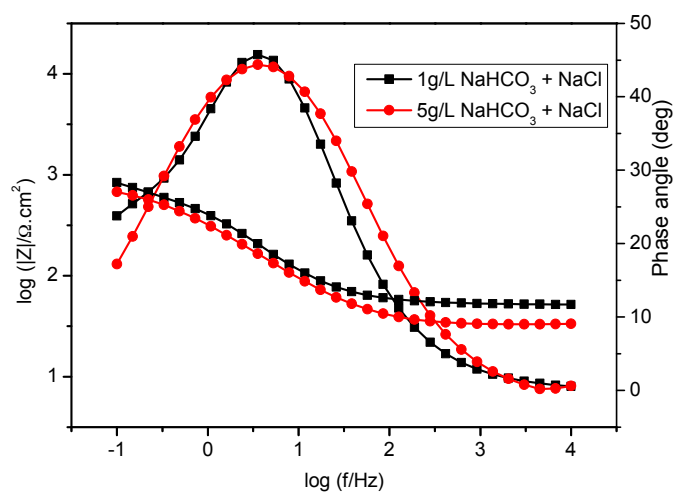

(b)

Figure 3. Impedance spectra for mild steel in bicarbonate chloride solution: (a) Nyquist plots and (b) Bode phase angle and impedance magnitude vs. frequency plots.

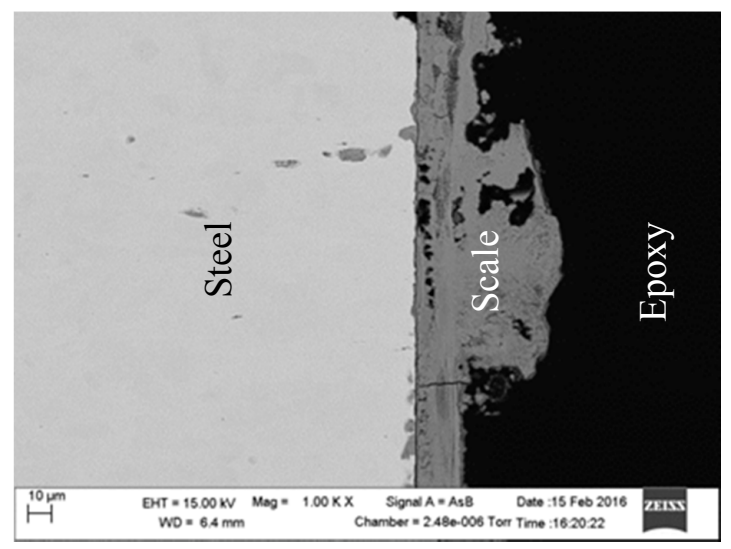

(a)

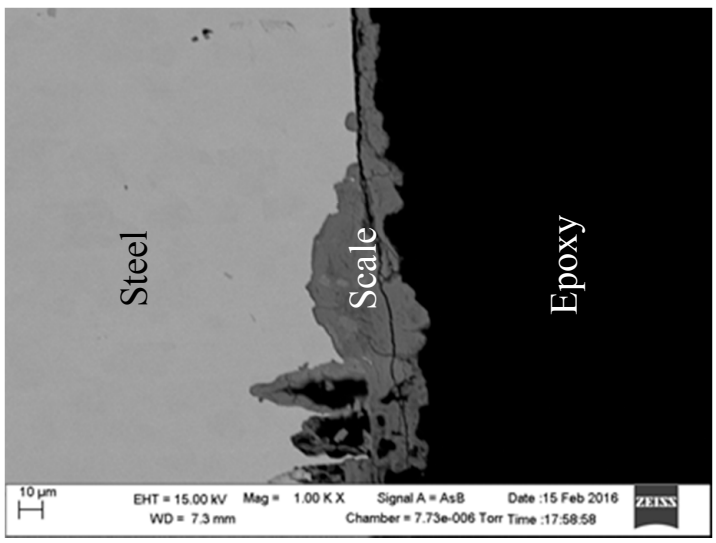

(b)

Figure 4. Cross-section of the scale formed at (a) $1 \mathrm{~g} / \mathrm{L}$ (b) $5 \mathrm{~g} / \mathrm{L}$ sodium bicarbonate/chloride solution at $2000 \mathrm{rpm}$.

\subsection{Dissolved Oxygen}

Dissolved oxygen concentration decreases with nitrogen purging time. In the present experiments, the nitrogen purging also led to a corresponding decrease in temperature as depicted in Figure 5. The test solution temperature was $\approx 24{ }^{\circ} \mathrm{C}$ at $0 \mathrm{~h}$ purging, with DO $\approx 4 \mathrm{ppm}$. The DO decreased significantly to $\approx 0.8$ ppm after $3 \mathrm{~h}$, at which point the temperature decreased to $\approx 18.6^{\circ} \mathrm{C}$. The decrease in temperature with purging time was due to the cooling effect of the cooler nitrogen gas.

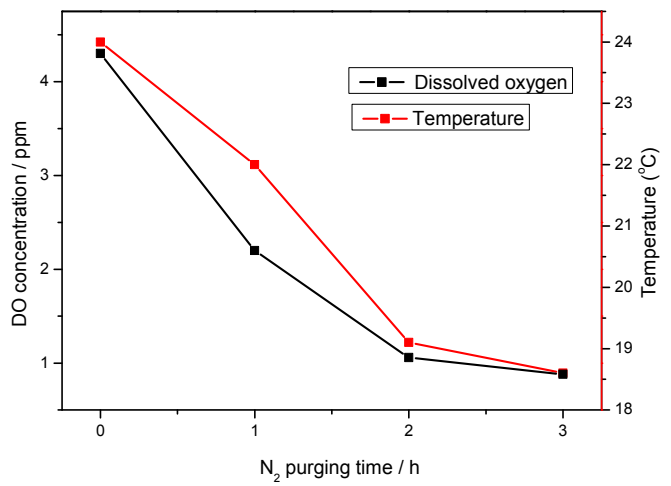

Figure 5. Dissolved oxygen (DO) concentration and temperature as a function of $\mathrm{N}_{2}$ purging time. 
Figure 6 shows the polarization curves of mild steel in bicarbonate/chloride solution in different DO concentrations at $2000 \mathrm{rpm}$. The anodic polarization increased without any retardation at a DO concentration of $4 \mathrm{ppm}$, whereas one anodic peak appeared in solutions containing $1 \mathrm{ppm}$ and $0.8 \mathrm{ppm}$ DO. The anodic polarization current increases with corrosion potentials below $\approx-600 \mathrm{mV}_{\mathrm{SCE}}$, indicating iron dissolution while at potentials greater than $\approx-600 \mathrm{mV}_{\mathrm{SCE}}$, the anodic current decreases indicating some form of passivation. A potential cause of this behaviour would be as a result of corrosion products. For example, $\mathrm{Fe}(\mathrm{OH})_{2}$ formed on the specimen surface, according to the following reaction:

$$
\mathrm{Fe}+2 \mathrm{H}_{2} \mathrm{O} \rightarrow \mathrm{Fe}(\mathrm{OH})_{2}+2 \mathrm{H}^{+}+2 \mathrm{e}^{-} \text {. }
$$

$\mathrm{Fe}(\mathrm{OH})_{2}$ forms a defective hydrous film barrier layer between the specimen and the solution, and consequently retards the anodic current density [34,35]. The corrosion current density decreased with decreasing DO concentration from $201.5 \mu \mathrm{A} \cdot \mathrm{cm}^{-2}$ to $22.3 \mu \mathrm{A} \cdot \mathrm{cm}^{-2}$ at $4 \mathrm{ppm}$ and $0.8 \mathrm{ppm}$, respectively, as shown in Table 1. This indicates that a more compact and stable oxide film was formed at $\approx-600 \mathrm{mV}_{\mathrm{SCE}}$ at lower $\mathrm{DO}$. The increase in anodic polarisation current with decreasing $\mathrm{DO}$ at a more noble potential could be attributed to the solubility of corrosion product as temperature decreases due to the cooling effect of $\mathrm{N}_{2}$ gas and insufficient oxidation at the steel surface to form oxide film other than through the Kuch mechanism.

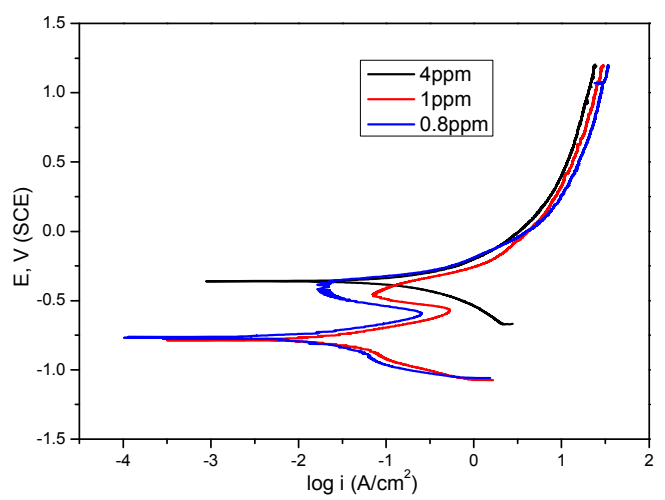

Figure 6. Potentiodynamic polarization of mild steel in $5 \mathrm{~g} / \mathrm{L}$ sodium bicarbonate /chloride solution in different dissolved oxygen concentrations at $2000 \mathrm{rpm}$.

Table 1. Polarization parameters for mild steel in $5 \mathrm{~g} / \mathrm{L}$ bicarbonate/chloride solution in different dissolved oxygen concentrations.

\begin{tabular}{|c|c|c|c|c|}
\hline$D O(\mathrm{ppm})$ & $I_{\text {corr }}\left(\mu \mathrm{A} \cdot \mathrm{cm}^{-2}\right)$ & $E_{\text {corr }}(\mathrm{mV})$ & $b_{a}\left(m V \cdot \operatorname{dec}^{-1}\right)$ & $-b_{c}\left(m V \cdot d^{-1}\right)$ \\
\hline 0.8 & 22.28 & -767.5 & 163.0 & 302.9 \\
\hline 1 & 25.24 & -780.6 & 138.5 & 222.9 \\
\hline 4 & 201.52 & -369.2 & 243.5 & 240.3 \\
\hline
\end{tabular}

Figure 7a,b show the Nyquist and Bode-phase angle plots for different DO concentrations in bicarbonate/chloride solution. The impedance semi-circle increases with decreasing DO, which implies that decreasing DO facilitates the formation of a more stable oxide layer at the steel surface. A similar trend can be seen in the Bode impedance magnitude spectra (Figure $7 \mathrm{~b}$ ), where the impedance increases with decreasing DO concentrations at low frequencies. The phase angle shows a higher peak as DO concentration decreases. A higher phase angle value at low frequency indicates a higher surface resistance at the steel. The increase in $R_{\mathrm{ct}}$ and a decrease in $Q_{\mathrm{dl}}$ with increasing DO from $1015 \Omega \cdot \mathrm{cm}^{2}$ at $0.8 \mathrm{ppm}$ to $104.7 \Omega \cdot \mathrm{cm}^{2}$ at $4 \mathrm{ppm}$ as shown in Table 2 can be attributed to oxide film formation. The film resistance $\left(R_{a}\right)$ increases significantly with decreasing DO concentration, suggesting that the corrosion product at the steel surface is more dense and protective at a relatively low $\mathrm{DO}$ as shown in Figure 8. 
Table 2. Impedance parameters for mild steel in bicarbonate/chloride solution in different dissolved oxygen concentrations.

\begin{tabular}{|c|c|c|c|c|c|c|}
\hline$D O(\mathrm{ppm})$ & $R_{s}\left(\Omega \cdot \mathrm{cm}^{2}\right)$ & $R_{c t}\left(\Omega \cdot \mathrm{cm}^{2}\right)$ & $Q_{d l}\left(\mathrm{~F} \cdot \mathrm{cm}^{-2}\right)$ & $n$ & $R_{a}\left(\Omega \cdot \mathrm{cm}^{2}\right)$ & $Q_{a}\left(\mathrm{~F} \cdot \mathrm{cm}^{-2}\right)$ \\
\hline 0.8 & 46.3 & 1015 & $1.76 \times 10^{-3}$ & 0.77 & 440.04 & $5.9 \times 10^{-4}$ \\
\hline 1 & 53.8 & 874.7 & $1.18 \times 10^{-3}$ & 0.66 & 90.49 & $1.39 \times 10^{-3}$ \\
\hline 4 & 63.5 & 104.7 & $6.88 \times 10^{-3}$ & 0.59 & 33.04 & $3.75 \times 10^{-3}$ \\
\hline
\end{tabular}

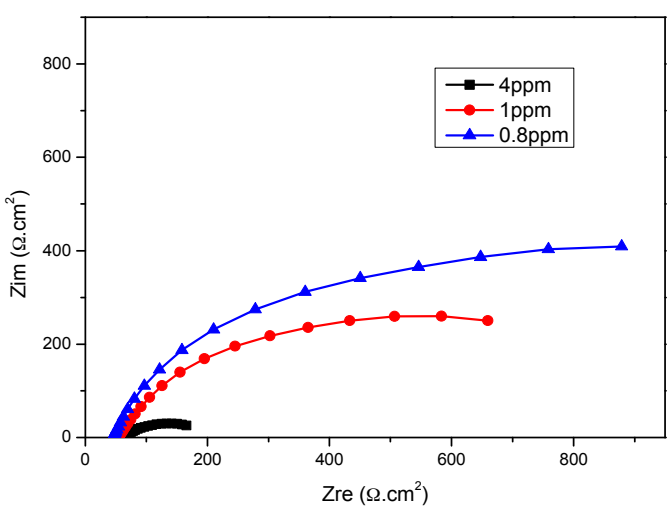

(a)

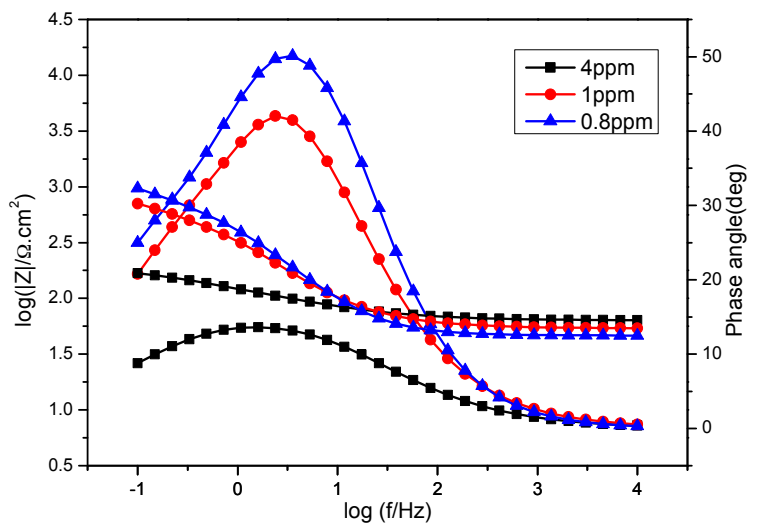

(b)

Figure 7. Impedance spectra for mild steel in $5 \mathrm{~g} / \mathrm{L}$ bicarbonate/chloride solution in different dissolved oxygen concentration at $2000 \mathrm{rpm}$ (a) Nyquist impedance plots (b) Bode and phase angle plots.

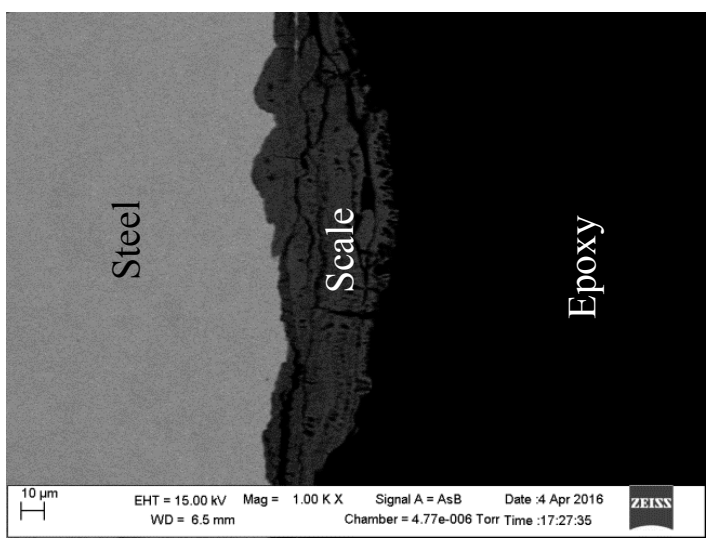

(a)

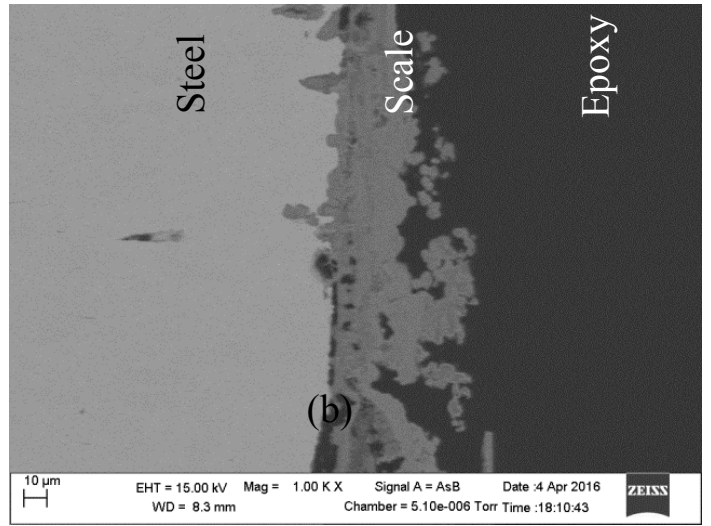

(b)

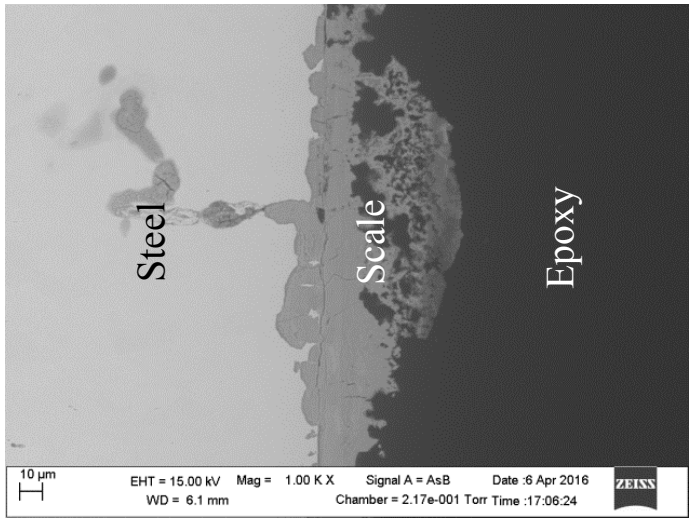

(c)

Figure 8. Cross-section of the scale formed at in $5 \mathrm{~g} / \mathrm{L}$ bicarbonate/chloride solution for (a) $4 \mathrm{ppm}$ (b) $1 \mathrm{ppm}$ (c) $0.8 \mathrm{ppm}$ dissolved oxygen at $2000 \mathrm{rpm}$. 


\subsection{Immersion Time}

Figure 9 contains polarization curves showing the effect of immersion time on mild steel in bicarbonate/chloride solution at $0.8 \mathrm{ppm}$ DO under dynamic conditions (2000 rpm) rotation speeds. The polarisation curves show that immersion time has a marked effect on anodic and cathodic polarization current. However, the effect was more apparent at corrosion potentials between ( -250 and + $250 \mathrm{mV}_{\mathrm{SCE}}$ ), where anodic potential current decreased with immersion time. The curve for each immersion time contains one anodic peak and, as expected, corrosion products on the steel surface become thicker and more compact with immersion time. Siderite can form in relatively low flow velocities at $\mathrm{pH}>5$, and the film thickness increases with time [16]. The passivation potential range becomes broader with increasing immersion time, with the pitting breakdown potential $\mathrm{E}_{\mathrm{b}}$ increasing from $\approx-355 \mathrm{mV}_{\mathrm{SCE}}$ at $2 \mathrm{~h}$ to $\approx-229 \mathrm{mV}_{\mathrm{SCE}}$ after $8 \mathrm{~h}$ immersion time as shown in Table 3.

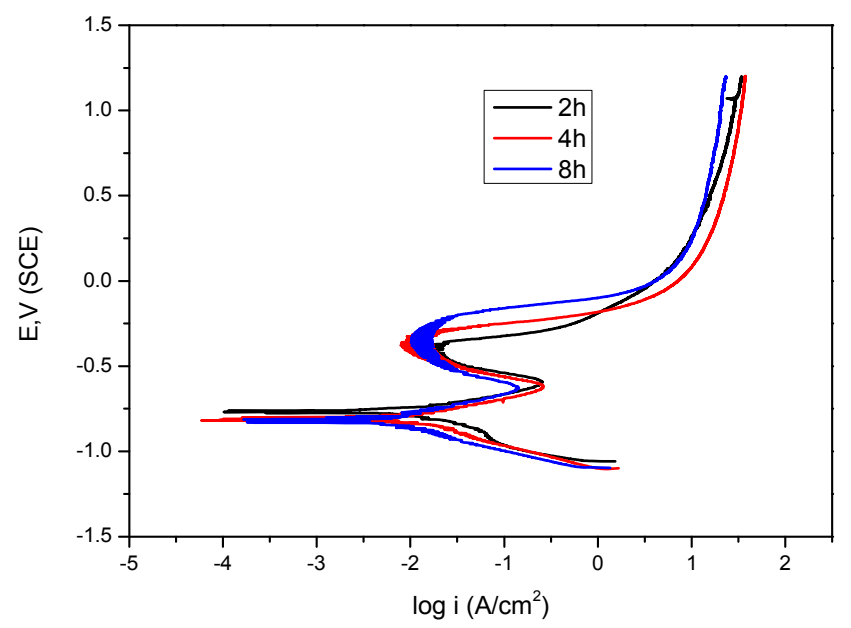

Figure 9. Potentiodynamic polarization for mild steel in $5 \mathrm{~g} / \mathrm{L}$ bicarbonate/chloride solution at different immersion times at $2000 \mathrm{rpm}$.

Table 3. Polarization parameters for mild steel in $5 \mathrm{~g} / \mathrm{L}$ bicarbonate/chloride solution for different immersion times at $2000 \mathrm{rpm}$.

\begin{tabular}{cccccc}
\hline Immersion Time $(\mathbf{h})$ & $\mathbf{I}_{\text {corr }}\left(\boldsymbol{\mu} \mathbf{A} \cdot \mathbf{c m}^{-\mathbf{2}}\right)$ & $\mathbf{E}_{\mathbf{b}}(\mathbf{m V})$ & $\mathbf{E}_{\mathbf{c o r r}}(\mathbf{m V})$ & $\mathbf{b}_{\mathbf{a}}\left(\mathbf{m V} \cdot \mathbf{d e c}^{-\mathbf{1}}\right)$ & $-\mathbf{b}_{\mathbf{c}}(\mathbf{m V} \cdot \mathbf{d e c}$ \\
\hline 2 & 22.28 & -355.0 & -767.5 & 163.0 & 302.9 \\
4 & 8.98 & -292.3 & -820.4 & 126.6 & 138.0 \\
8 & 6.04 & -229.1 & -833.9 & 145.6 & 134.8 \\
\hline
\end{tabular}

Figure 10 shows the Nyquist plots and Bode phase angle plots of mild steel in bicarbonate/chloride solution at $0.8 \mathrm{ppm}$ DO at different immersion times at $2000 \mathrm{rpm}$. The Nyquist plots in Figure 10a show that the diameter of the semi-circle increases with immersion time, which implies that the steel surface resistance improves with immersion time. The result is consistent with more corrosion product being deposited on the the steel surface, and forming a relatively inert surface barrier at the steel-solution interface. The charge transfer resistance $\left(R_{c t}\right)$ increased from $1015 \Omega \cdot \mathrm{cm}^{2}$ to $2700 \Omega \cdot \mathrm{cm}^{2}$ in going from $2 \mathrm{~h}$ to $8 \mathrm{~h}$ immersion time as shown in Table 4, presumably as a result of deterioration of the oxide film on the steel surface. A similar result was reported in our previous work [31]. The Bode impedance magnitude plots show similar trends. The impedance magnitude and the phase angle increase with immersion time as evident in Bode plots at low frequencies as shown in Figure 10b, implying that the corrosion product at the steel surface becomes denser and more protective with immersion time, as is evident in Figure 11. It would therefore be expected that metal dissolution would be retarded, in agreement with the data obtained from polarization curves. 
Table 4. Impedance parameters for mild steel in bicarbonate/chloride solution for different immersion times.

\begin{tabular}{|c|c|c|c|c|c|c|}
\hline Immersion Time (h) & $R_{S}\left(\Omega \cdot \mathrm{cm}^{2}\right)$ & $R_{c t}\left(\Omega \cdot \mathrm{cm}^{2}\right)$ & $Q_{d l}\left(\mathrm{~F} \cdot \mathrm{cm}^{-2}\right)$ & $n$ & $R_{a}\left(\Omega \cdot \mathrm{cm}^{2}\right)$ & $Q_{a}\left(\mathrm{~F} \cdot \mathrm{cm}^{-2}\right)$ \\
\hline 2 & 46.3 & 1015 & $1.76 \times 10^{-3}$ & 0.77 & 440.04 & $5.9 \times 10^{-4}$ \\
\hline 4 & 30.5 & 1370 & $1.65 \times 10^{-3}$ & 1 & 804.0 & $5.04 \times 10^{-4}$ \\
\hline 8 & 41.6 & 2700 & $7.28 \times 10^{-4}$ & 0.82 & 618.6 & $5.83 \times 10^{-4}$ \\
\hline
\end{tabular}

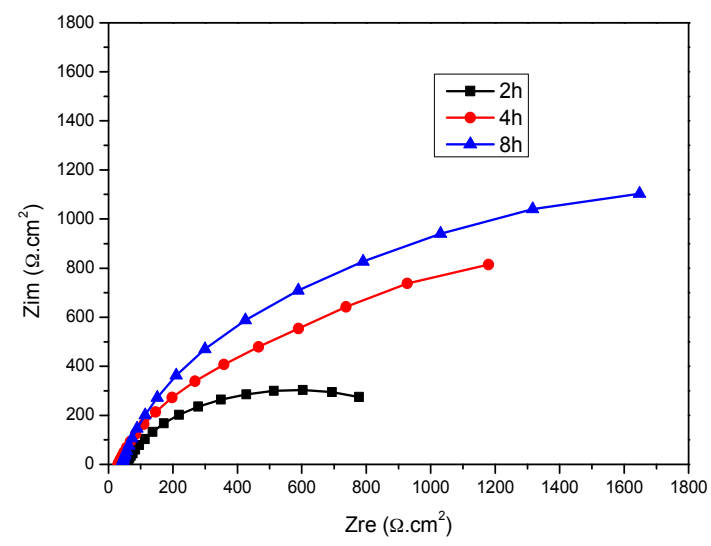

(a)

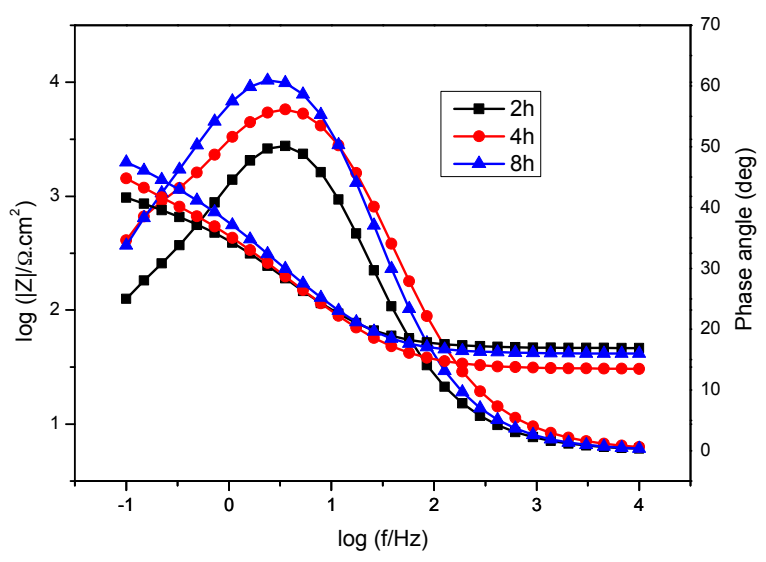

(b)

Figure 10. Impedance spectra for mild steel in $5 \mathrm{~g} / \mathrm{L}$ bicarbonate/chloride solution at different immersion times at $2000 \mathrm{rpm}$ (a) Nyquist impedance plots (b) Bode and phase angle plots.
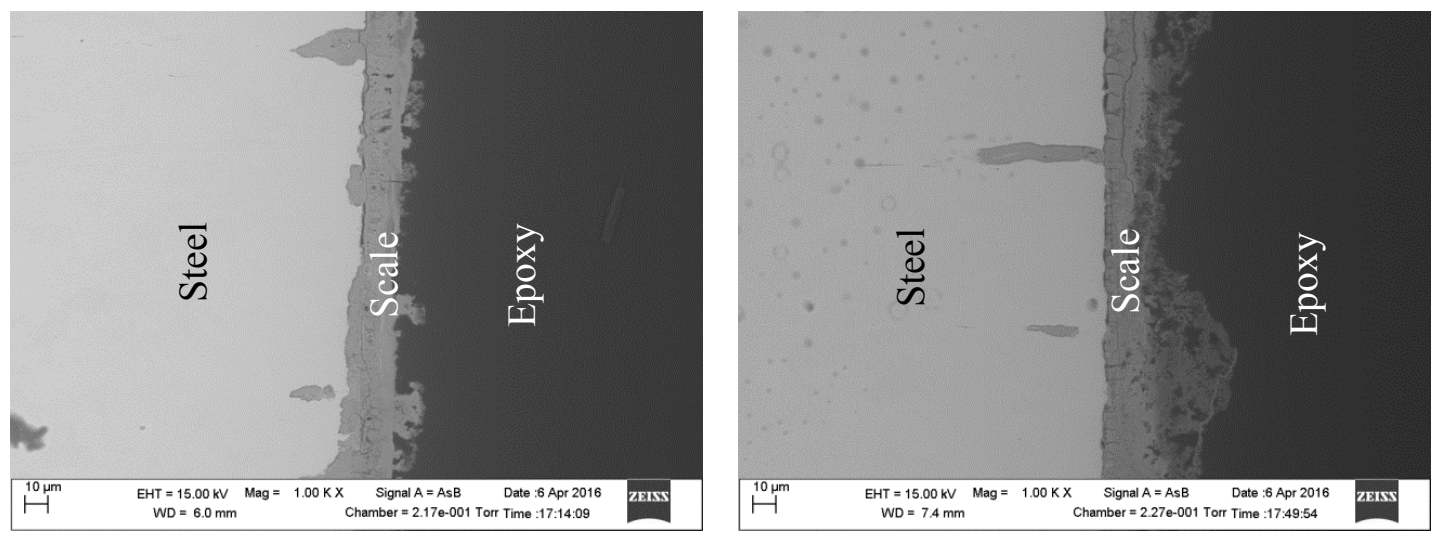

(a) (b)

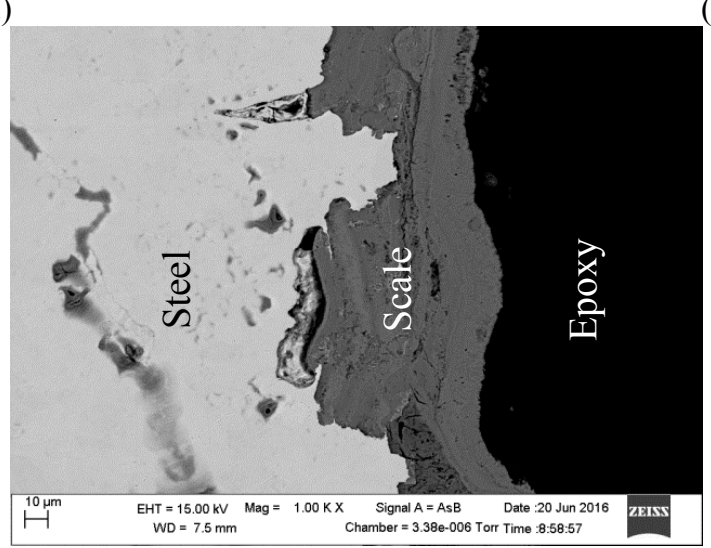

(c)

Figure 11. Cross-section of the scale formed in $5 \mathrm{~g} / \mathrm{L}$ sodium bicarbonate/chloride solution at $2000 \mathrm{rpm}$ after (a) $2 \mathrm{~h} \mathrm{(b)} 4 \mathrm{~h}$ and (c) $8 \mathrm{~h}$ immersion times. 


\subsection{Surface Analysis}

Figure 12 shows scanning electron micrographs obtained from the surfaces of samples immersed in $1 \mathrm{~g} / \mathrm{L}$ and $5 \mathrm{~g} / \mathrm{L}$ bicarbonate chloride solutions at $2000 \mathrm{rpm}$. The SEM results show that pits with relatively small diameters of a few microns were predominant with specimen in low bicarbonate concentration. The density of pits decreased in the sample exposed to $5 \mathrm{~g} / \mathrm{L}$ bicarbonate solution, but the pits became much larger both in depth and width. Figure 13a-c show the surface morphologies of specimens after corrosion tests in bicarbonate/chloride solution at different dissolved oxygen (DO) concentrations. The micrographs revealed that the corrosion damage decreases with decreasing dissolved oxygen due to more tenacious oxide film on the steel-solution interface, as shown in Figure 13c for solution containing $0.8 \mathrm{ppm}$ DO. Our cross-sectional images (Figure 11) show that the oxide film thickness increases with immersion time, the film morphology also varies with immersion time as shown in Figure 14 providing a barrier layer at the metal-solution interface, and as a result the surface damage also decreases, ranging from pitting corrosion to general corrosion, as shownin Figure 15.

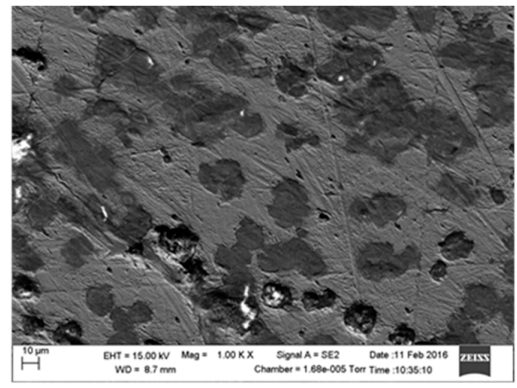

(a)

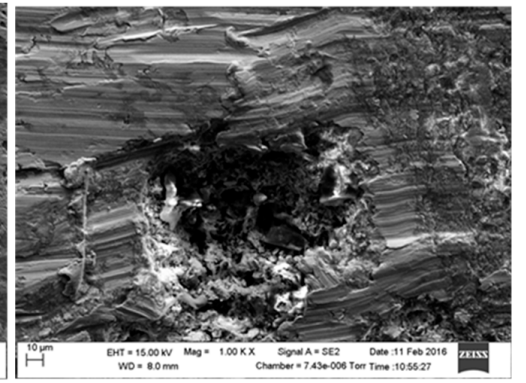

(b)

Figure 12. Scanning Electron Microscopy micrographs of mild steel in $5 \mathrm{~g} / \mathrm{L}$ bicarbonate/chloride solution at $2000 \mathrm{rpm}$ : (a) $1 \mathrm{~g} / \mathrm{L}$ and (b) $5 \mathrm{~g} / \mathrm{L}$ bicarbonate solution.

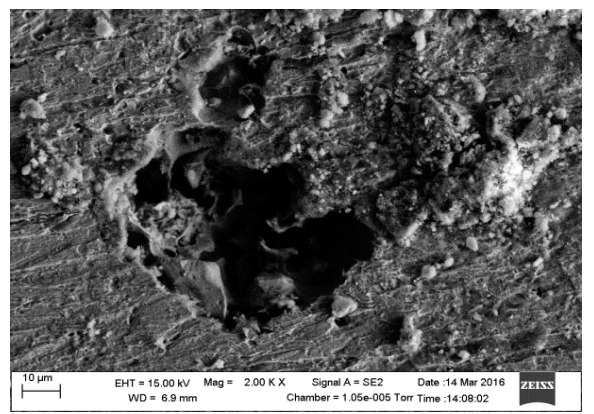

(a)

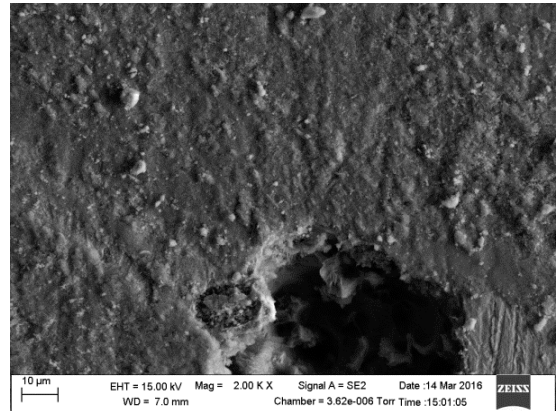

(b)

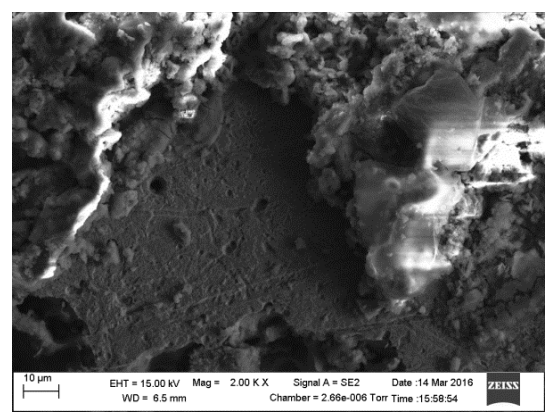

(c)

Figure 13. Scanning Electron Microscopy micrograph in $5 \mathrm{~g} / \mathrm{L}$ bicarbonate/chloride solution at 2000 rpm: (a) 4 ppm (b) 1 ppm (c) 0.8 ppm dissolve oxygen. 


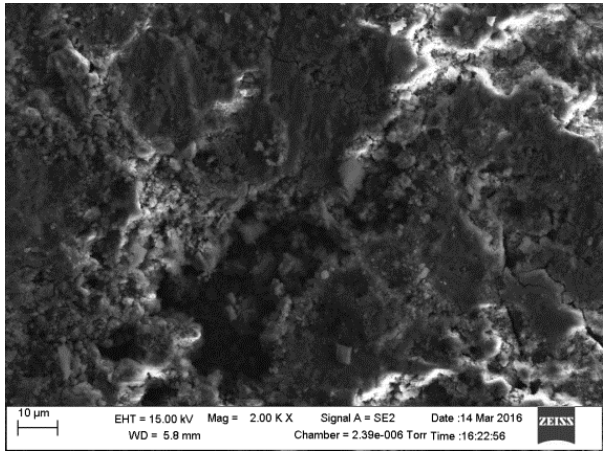

(a)

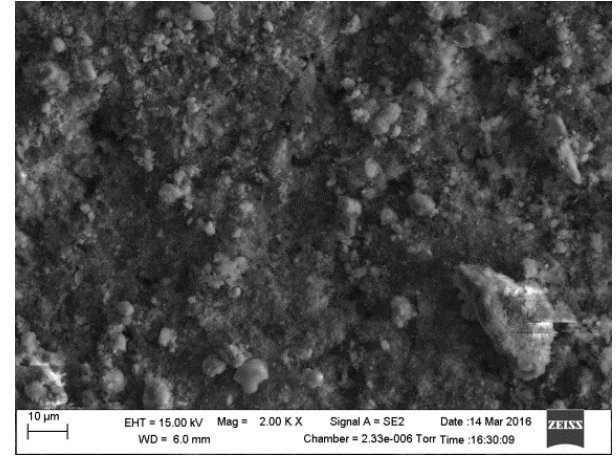

(b)

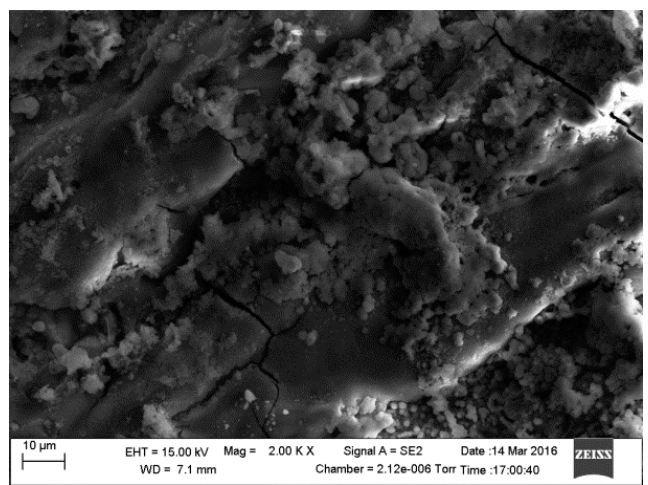

(c)

Figure 14. Scanning Electron Microscopy micrographs of mild steel in $5 \mathrm{~g} / \mathrm{L}$ bicarbonate/chloride solution at $2000 \mathrm{rpm}$ before cleaning: (a) $2 \mathrm{~h}$ (b) $4 \mathrm{~h}$ (c) $8 \mathrm{~h}$ immersion time.

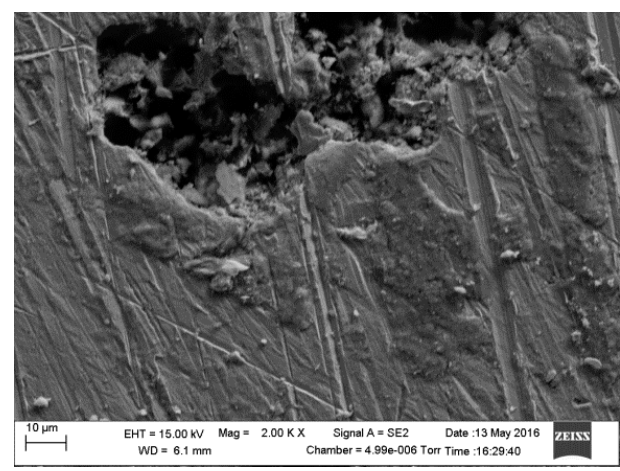

(a)

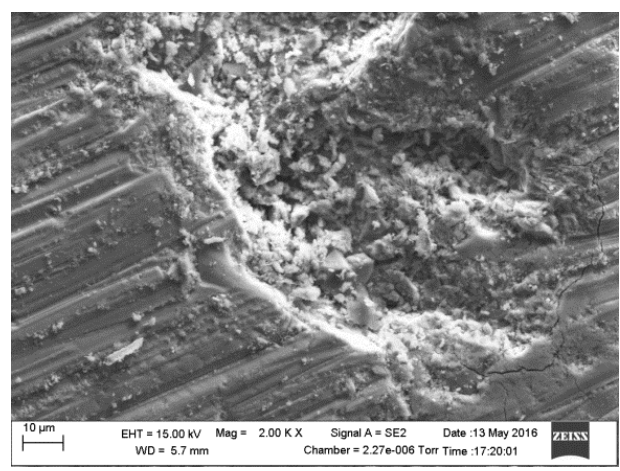

(b)

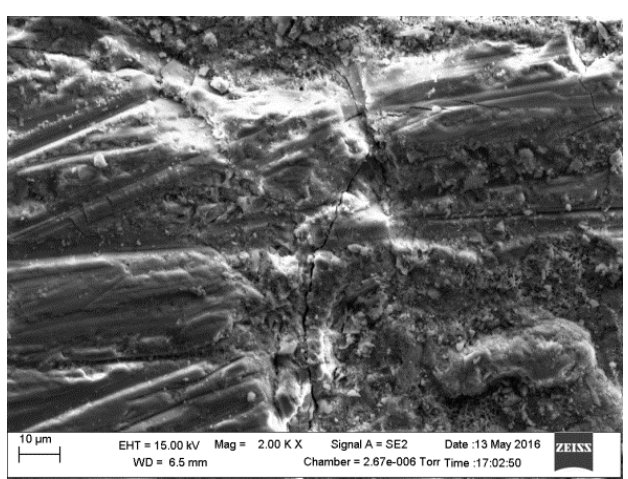

(c)

Figure 15. Scanning Electron Microscopy micrographs of mild steel in $5 \mathrm{~g} / \mathrm{L}$ bicarbonate/chloride solution at $2000 \mathrm{rpm}$ after cleaning: (a) $2 \mathrm{~h} \mathrm{(b)} 4 \mathrm{~h} \mathrm{(c)} 8 \mathrm{~h}$ immersion time. 
The corrosion pit density and pit depth in specimens immersed in $1 \mathrm{~g} / \mathrm{L}$ and $5 \mathrm{~g} / \mathrm{L}$ bicarbonate were further studied using Leica optical microscopy. The results show that the corrosion pit density decreases while the depth increases with bicarbonate concentration. The pit depth increases from $\approx-8 \mu \mathrm{m}$ to $\approx-60 \mu \mathrm{m}$ for $1 \mathrm{~g} / \mathrm{L}$ and $5 \mathrm{~g} / \mathrm{L}$, respctively, as shown in Figure 16.

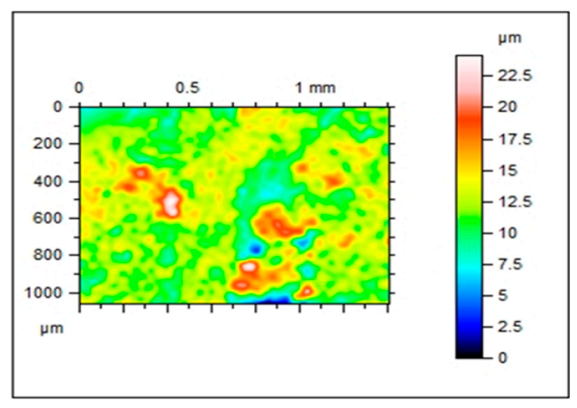

(a)
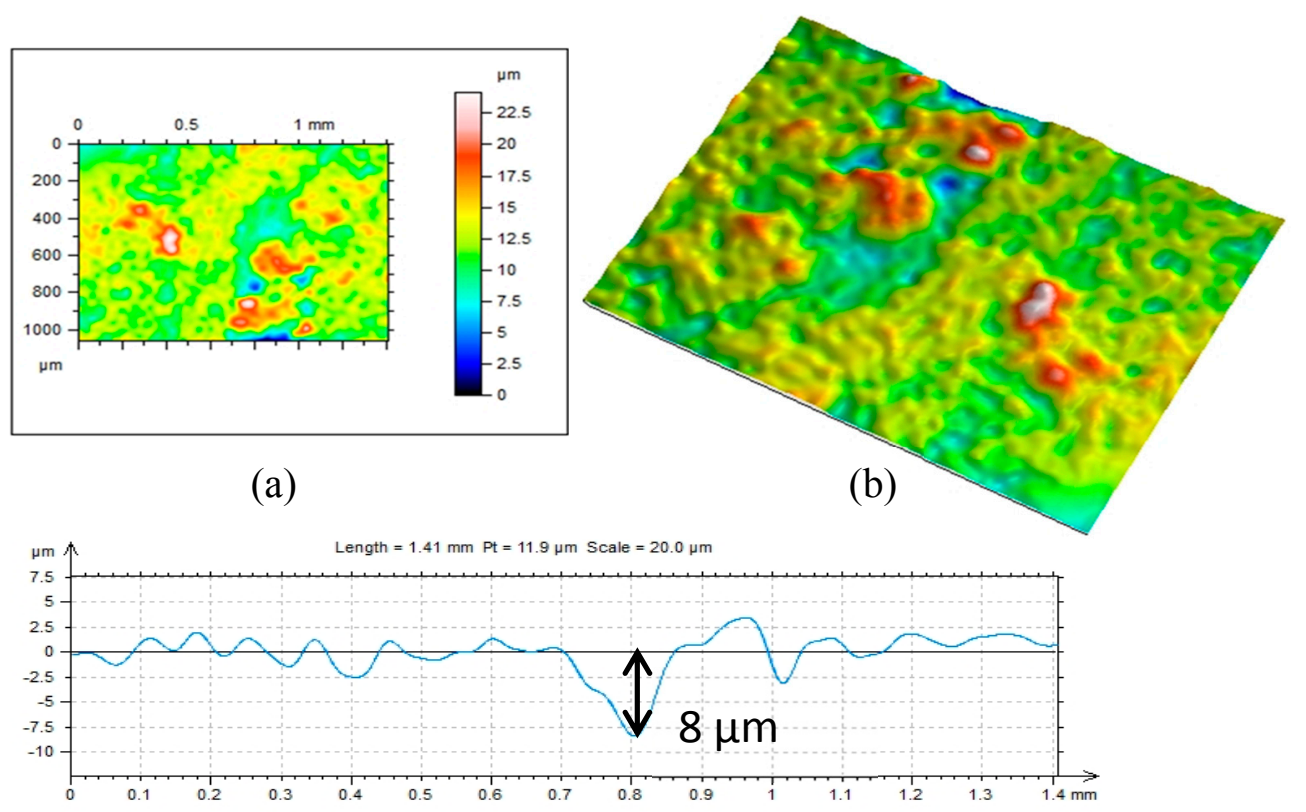

(c)

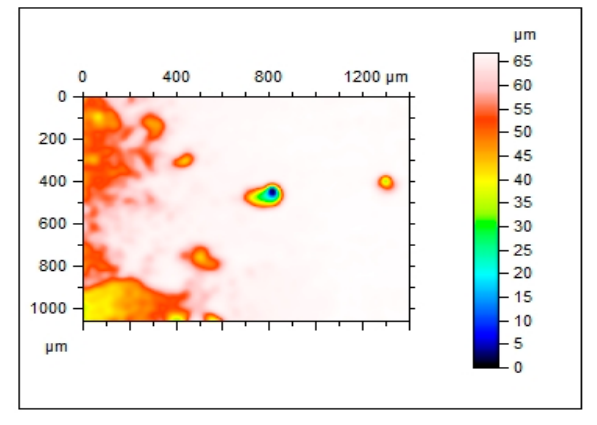

(d)

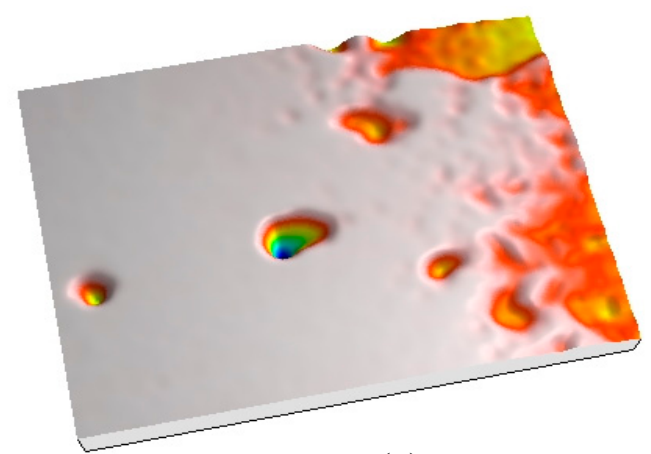

(e)

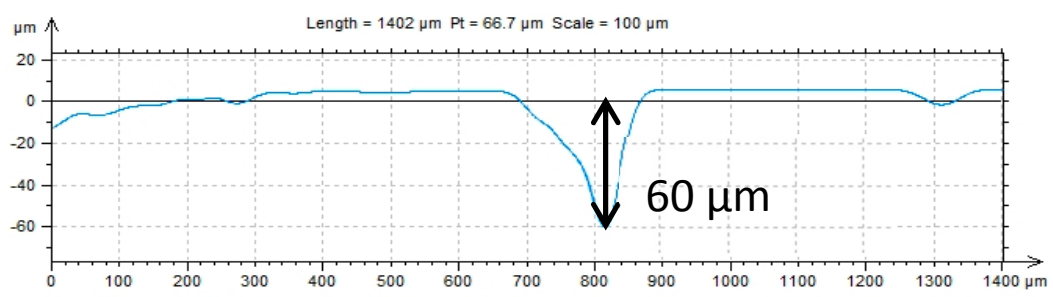

(f)

Figure 16. Topography profile and 3D image of pit affected area: (a-c) $1 \mathrm{~g} / \mathrm{L}$ and (d-f) $5 \mathrm{~g} / \mathrm{L}$ bicarbonate/chloride solution.

The corrosion pit density and pit depth in specimens immersed in $1 \mathrm{~g} / \mathrm{L}$ and $5 \mathrm{~g} / \mathrm{L}$ bicarbonate were further studied using Leica optical microscopy. The results show that the corrosion pit density decreases while the depth increases with bicarbonate concentration [36]. The pit depth increases from $\approx 8 \mu \mathrm{m}$ to $\approx 60 \mu \mathrm{m}$ for $1 \mathrm{~g} / \mathrm{L}$ and $5 \mathrm{~g} / \mathrm{L}$, respctively, as shown in Figure 16. The dissolution of iron is 
accelerated in the presence of bicarbonate owing to the formation of the stable soluble complex anion $\mathrm{Fe}\left(\mathrm{CO}_{3}\right)_{2}{ }^{2-}$ as reported in [3]. As more corrosion product is formed at the metal surface, galvanic couples could occur between steel surfaces covered with corrosion products (cathode) and uncovered active site (anode). This unstable thermodynamic condition accelerates the initiation and propagation of localized corrosion as shown in Figure 17.

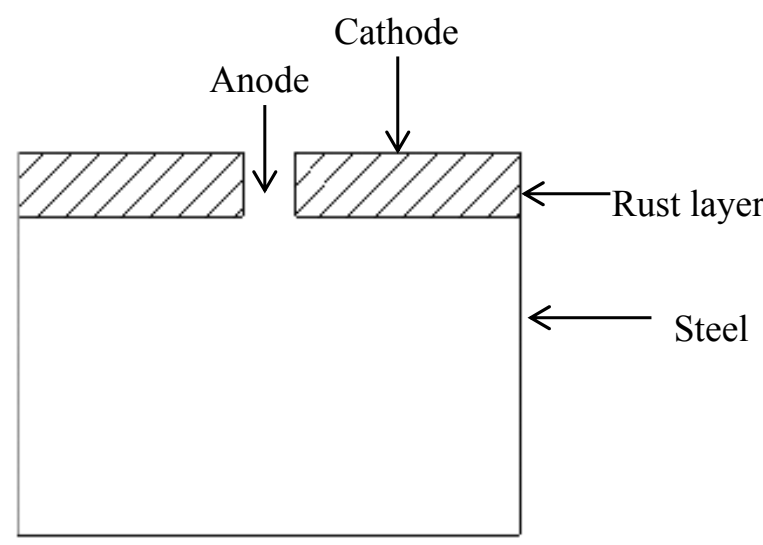

(a)

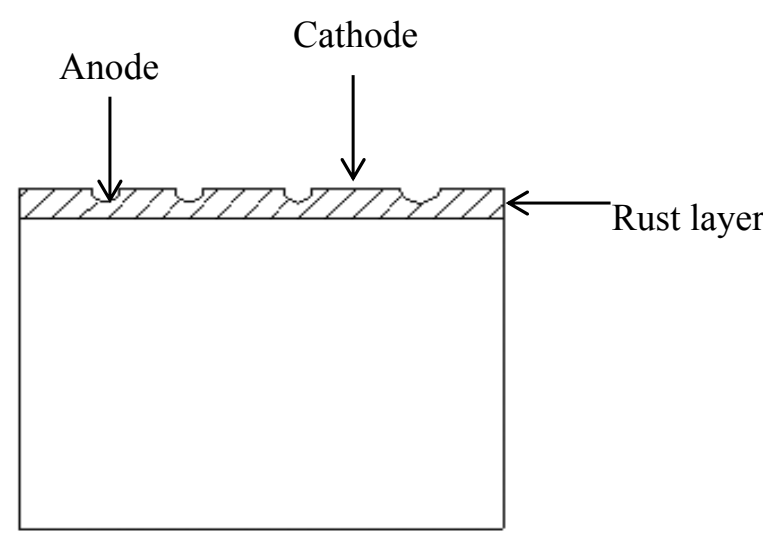

(c)

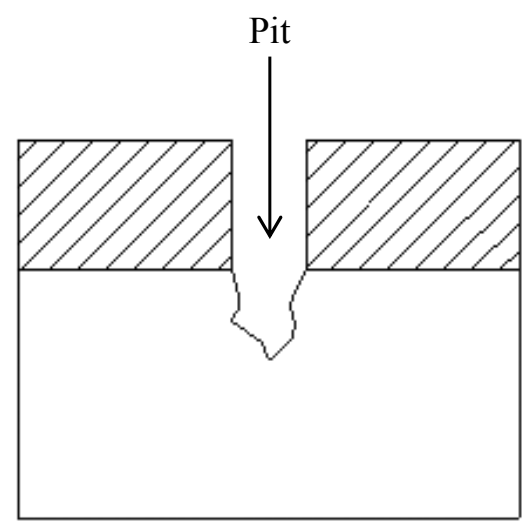

(b)

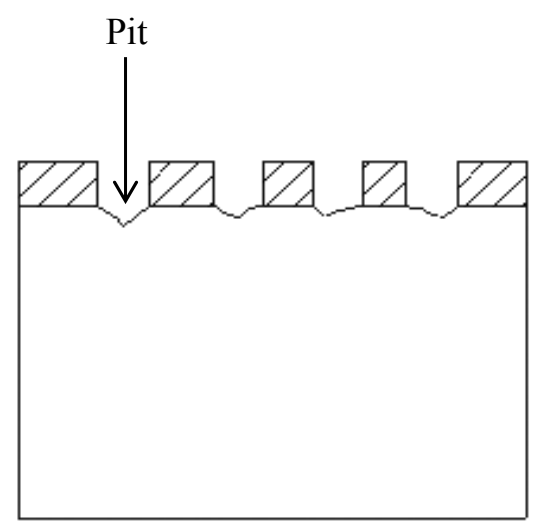

(d)

Figure 17. Schematic mechanism of bicarbonate concentration effect: $(\mathbf{a}, \mathbf{b}) 5 \mathrm{~g} / \mathrm{L} \mathrm{NaHCO}_{3}(\mathbf{c}, \mathrm{d}) 1 \mathrm{~g} / \mathrm{L}$ $\mathrm{NaHCO}_{3}$ concentration.

\subsection{XRD Analyses}

Figure 18 shows the XRD patterns for specimens immersed in bicarbonate chloride containing solution at $2000 \mathrm{rpm}$. Figure 18a-c show the peak patterns for unimmersed and immersed specimens in different bicarbonate concentrations. The elemental composition of the corrosion products tested under different bicarbonate concentrations show similarities in their chemical composition. However, the XRD patterns in Figure 18b indicate diffraction peaks of mainly Fe (iron) (44.3\%) and a single peak for $\beta-\mathrm{FeO}(\mathrm{OH})$ (akaganeite) (16.32\%) and $\gamma-\mathrm{FeO}(\mathrm{OH})$ (lepidocrocite) $(39.34 \%)$, in contrast to the peak patterns in Figure $18 \mathrm{c}$, with multiple peaks of both $(\alpha-\mathrm{FeO}(\mathrm{OH})$ goethite $(58.16 \%)$ and $\beta-\mathrm{FeO}(\mathrm{OH})$ (akaganeite) $(6.20 \%)$. The multiple peaks could probably be due to the density of the corrosion products on the steel surface. The formation of akaganeite confirms the presence of chloride ions in the corrosion products [31,37]. The relatively high amount of akaganeite in the specimen immersed in $1 \mathrm{~g} \cdot \mathrm{L}^{-1}$ bicarbonate/chloride solution implies that the corrosion product contains more chloride ions. Figure 18d,e show the XRD peak patterns for specimens immersed in $5 \mathrm{~g} \cdot \mathrm{L}^{-1}$ bicarbonate/chloride containing different dissolved oxygen concentrations. Goethite $(\alpha-\mathrm{FeO}(\mathrm{OH}))$, siderite $\mathrm{FeCO}_{3}$ and 
maghemite $\left(\gamma-\mathrm{Fe}_{2} \mathrm{O}_{3}\right)$ were formed at each DO concentration. However, more siderite $\mathrm{FeCO}_{3}$ and maghemite $\left(\gamma-\mathrm{Fe}_{2} \mathrm{O}_{3}\right)$ peaks are evident as DO decreases, as shown in Figure 18e.

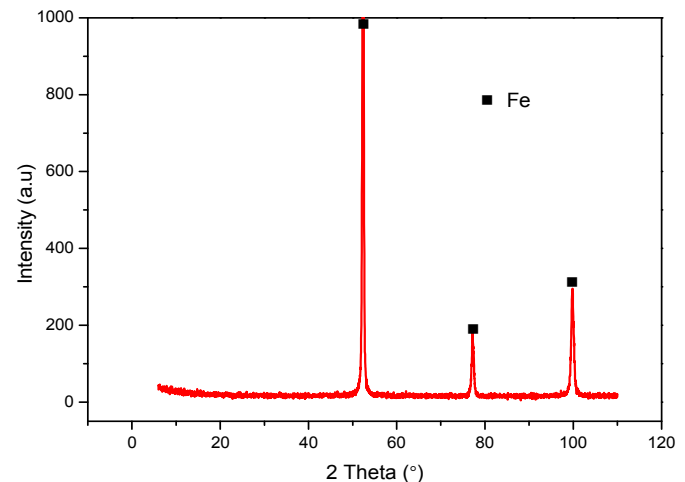

(a)

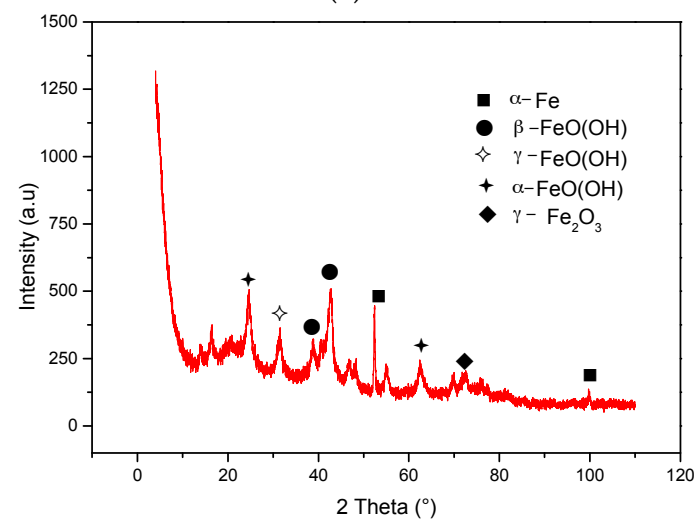

(c)

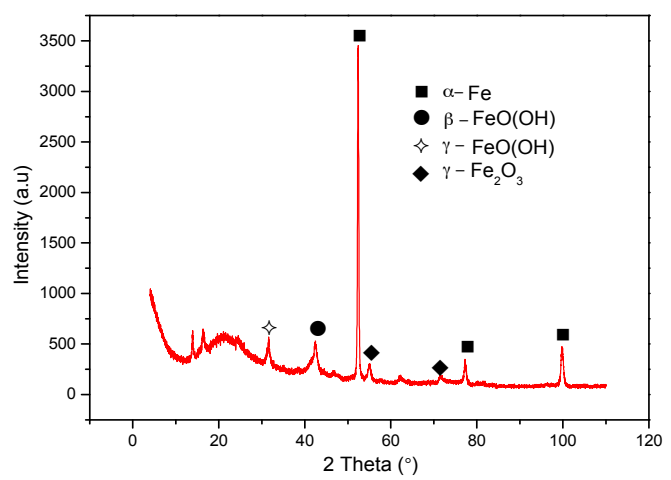

(b)

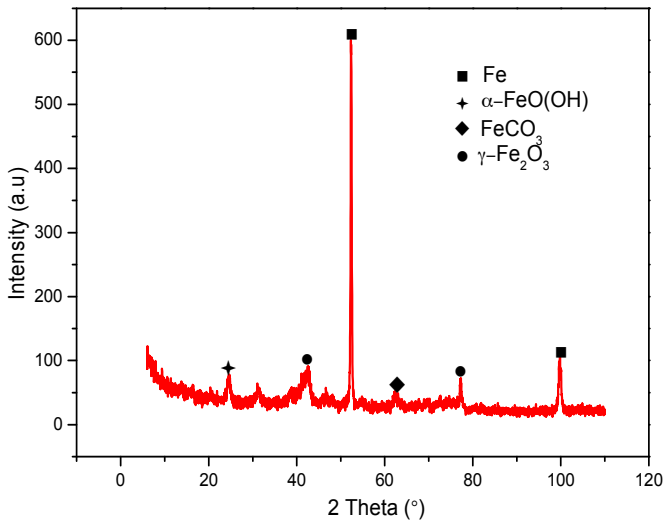

(d)

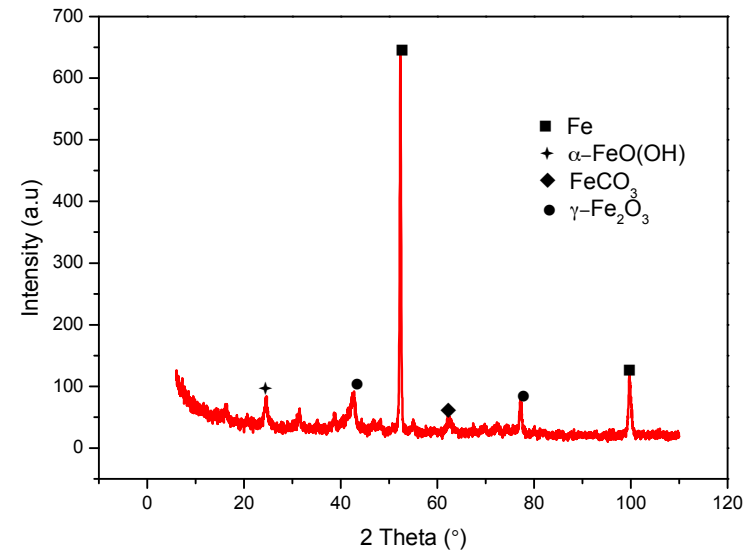

(e)

Figure 18. XRD analysis of corrosion products of mild steel in bicarbonate solutions containing chloride at $2000 \mathrm{rpm}$ : (a) unimmersed (b) $1 \mathrm{~g} / \mathrm{L}$ and (c) $5 \mathrm{~g} / \mathrm{L}$ bicarbonate (d) 4 ppm (e) 1 ppm.

\subsection{XPS Analyses}

Prior to XPS measurements, samples were sputtered for 60 min using $2 \mathrm{keV} \mathrm{Ar}^{+}$ions to remove adsorbed surface contamination and reveal the underlying chemistry in more detail. Argon sputtering is known to convert $\mathrm{FeCO}_{3}$ to $\mathrm{FeO}$ [38], and, correspondingly, we did not observe $\mathrm{FeCO}_{3}$, which can be identified from its high-binding-energy contribution to $C 1 \mathrm{~s}$, in our spectra. All spectra were calibrated to the $\mathrm{C}-\mathrm{C}$ adventitious carbon peak at $284.8 \mathrm{eV}$. In each spectrum, the dominant $\mathrm{C} 1 \mathrm{~s}$ component was identified as adventitious $\mathrm{C}-\mathrm{C}$. In each case, this peak had the expected companion $\mathrm{C}-\mathrm{O} / \mathrm{C}=\mathrm{O}$ peaks at higher binding energy. The $\mathrm{O} 1$ s spectra of the two samples (Figure 19) were similar, and could be 
deconvolved into two peaks: a relatively sharp peak near $530 \mathrm{eV}$ (dark gray component) and a broader peak centred near $531 \mathrm{eV}$ (light gray component). The lower binding energy peak has the expected shape and location for $\mathrm{O}^{2-}$ in iron oxides $\left(\mathrm{Fe}_{3} \mathrm{O}_{4}, \alpha-\mathrm{FeO}(\mathrm{OH})\right.$ and $\left.\mathrm{FeO}\right)$. The broader, higher binding energy peak is consistent with the $\mathrm{OH}^{-}$oxygens in $\alpha-\mathrm{FeO}(\mathrm{OH})$, as well as with the $\mathrm{C}-\mathrm{O}$ contribution from adventitious carbon. The analysis of Fe $2 p$ is complicated due to the multiplet structure of Fe $2 p$ peaks for high-spin compounds comprising $\mathrm{Fe}^{2+}$ and $\mathrm{Fe}^{3+}$ [39]. The multiplet structure manifests in a broad, asymmetric peak shape, particularly when measured with unmonochromated radiation as in the present measurements, making deconvolution of contributions from multiple chemical states difficult, and hence we offer only a qualitative analysis of the Fe 2p spectra shown in Figure 19. As with $\mathrm{O} 1 \mathrm{~s}$, the samples show similar peak shapes. The spectral weight in each sample is centred near $710 \mathrm{eV}$, consistent with contributions from $\mathrm{Fe}_{3} \mathrm{O}_{4}$ and $\alpha-\mathrm{FeO}(\mathrm{OH})$.

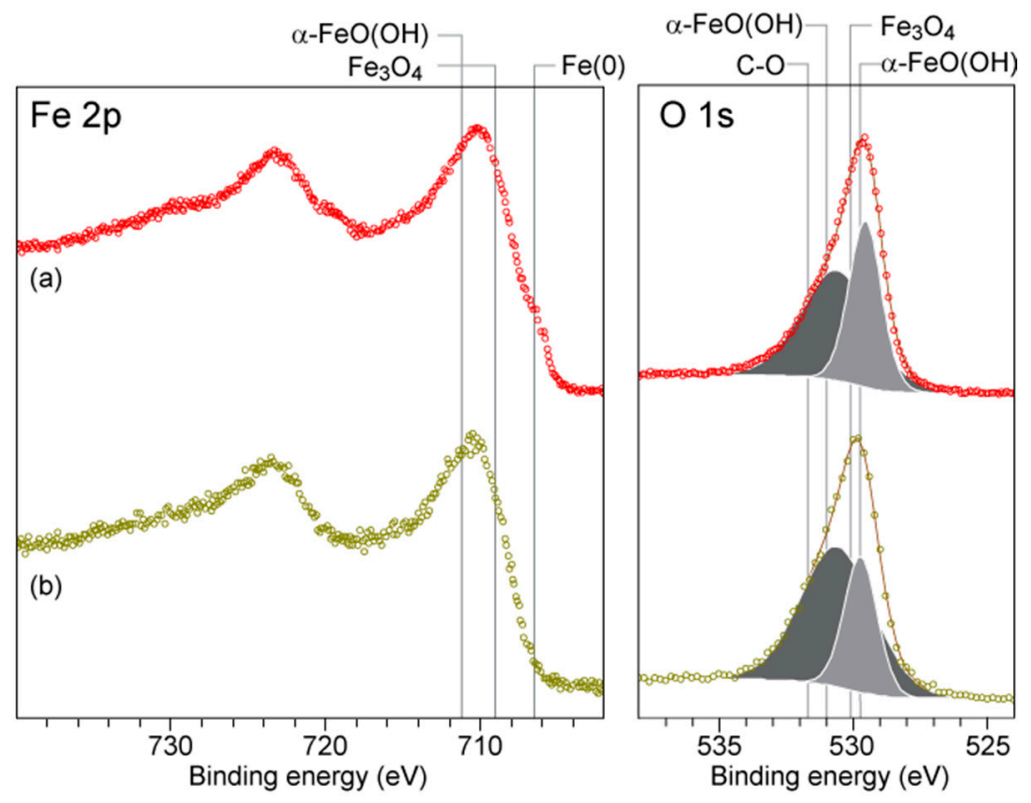

Figure 19. XPS collected from the Fe $2 p$ (left) and O 1 s (right) regions of Samples: (a) $1 \mathrm{~g} / \mathrm{L}$ and (b) $5 \mathrm{~g} / \mathrm{L}$. The Fe $2 \mathrm{p}$ data are presented without background subtraction, and without deconvolution of the peaks. The $\mathrm{O} 1 \mathrm{~s}$ data have had a Shirley background subtracted and have been deconvolved into two contributions. The indicated positions for different chemical states are approximate, and are based on values taken from $[38,39]$.

\section{Experimental Section}

\subsection{Materials and Solutions}

Cylindrical carbon steel rod $(\varnothing 16 \mathrm{~mm}$ ) of grade AISI 1020 was utilized as the rotating disc electrode (RDE). The chemical composition of the as-received rod was analyzed using a Field Emission Electron Probe Microanalyzer (JXA-8530F) with results shown in Table 5. The test samples were polished using emery papers of grit sizes ranging from 220 to 800 . Two solutions were prepared by dissolving analytical grade sodium bicarbonate $(1 \mathrm{~g}, 5 \mathrm{~g})$ and $2 \mathrm{~g}$ of sodium chloride in $1 \mathrm{~L}$ of distilled deionized water. The solutions were deaerated by bubbling nitrogen gas three hours before sample immersion to study the effect of bicarbonate concentrations and immersion time. To study the effects of dissolved oxygen, nitrogen gas was bubbled for $0 \mathrm{~h}, 2 \mathrm{~h}$ and $3 \mathrm{~h}$ which resulted in $4 \mathrm{ppm}, 1 \mathrm{ppm}$ and $0.8 \mathrm{ppm}$ DO concentrations, respectively, before sample immersion. The electrochemical tests were performed at ambient temperature $\left(22 \pm 3^{\circ} \mathrm{C}\right)$ at $\mathrm{pH}(8.2 \pm 0.1)$. 
Table 5. Chemical composition of mild steel (wt \%).

\begin{tabular}{ccccccc}
\hline $\mathbf{C}$ & $\mathbf{S i}$ & $\mathbf{M n}$ & $\mathbf{C r}$ & $\mathbf{C u}$ & $\mathbf{N i}$ & $\mathbf{F e}$ \\
\hline 0.20 & 0.32 & 0.79 & 0.01 & 0.01 & 0.01 & $\mathrm{Bal}$ \\
\hline
\end{tabular}

\subsection{Electrochemical Test}

The corrosion tests were carried out in a $1 \mathrm{~L}$ glass cell containing the rotating disk electrode (working electrode) fitted into rotating shaft of an analytical rotator AFASRE 747 (Pine Instrument). The reference electrode was a saturated calomel electrode (SCE) connected to the cell by a bridge and a Lugging capillary Platinum was used as counter electrode. The angular speed $(\omega)$ of the rotating disc electrode was controlled by the ASR RDE speed controller. The rotation speed of the RDE performed in the tests was $2000 \mathrm{rev} / \mathrm{min}$, respectively. Corrosion evaluation was monitored by potentiodynamic polarization and electrochemical impedance spectroscopy (EIS). The tests were performed at a scan rate of $(0.167 \mathrm{mV} / \mathrm{s})$ using a Bio-Logic instrument Model VSP 0508 potentiostat. The potentiodynamic polarisation was obtained from a starting potential of $-0.30 \mathrm{~V}$ vs. SCE to a final potential of $+1.20 \mathrm{~V}$ vs. SCE. Electrochemical impedance spectroscopy measurements were conducted at open-circuit. Measuring frequencies ranged from $10 \mathrm{kHz}$ to $0.1 \mathrm{~Hz}$ with a perturbing alternating current (AC) amplitude of $10 \mathrm{mV}$ and a sampling rate of 10 points per decade.

\subsection{Surface Analysis}

Scanning electron microscopy (SEM) imaging was performed after corrosion tests using a Zeiss Sigma VP Field Emission Scanning Electron Microscope (Oxford XMax 50 silicon drift energy dispersive spectroscopy EDS detector) in secondary electron (SE) image mode with an accelerating beam voltage of $15 \mathrm{kV}$. Pit volume and pit depth were examined using Leica Optical microscopy Model DFC 490.

\subsection{X-ray Diffraction}

The corrosion products were characterized in-situ using a PANalytical X'pert PRO MPD powder X-ray Diffractometer (XRD) equipped with a $40 \mathrm{keV}, 40 \mathrm{~mA}, \mathrm{Co} \mathrm{K}_{\alpha}$. A parabolic mirror optic on the incident side, 0.04 rad Soller slits on the source and detector side, and $0.09^{\circ}$ collimator before the detectors were used to give a parallel beam. The incident angle $(\omega)$ was fixed to $3^{\circ}$ and data collected from $6^{\circ}$ to $90^{\circ}(2 \theta)$. The other slits were optimized to ensure the beam footprint did not exceed the sample dimensions or the detector window opening. Quantitative phase analysis was performed in TOPAS (V5, Bruker). An instrument function collected from SRM 660a was used to accurately model peak shape and width. Fixed incident parallel beam intensity and peak width corrections according to Rowles and Madsen [40], Toraya et al. [41] and Haggerty et al. [42] were employed. The values of these corrections were fixed to those for the instrument function when refining the sample data. Other parameters refined included background, scale factors for each phase, specimen displacement, unit cell parameters for each phase, and a Lorentzian crystallite size term for each phase.

\subsection{X-ray Photoelectron Spectroscopy}

XPS measurements were performed using a non-monochromatized $\mathrm{Al} \mathrm{K} \alpha(1486.7 \mathrm{eV})$ source (DAR 400, ScientaOmicron $\mathrm{GmbH}$ ) with a $125 \mathrm{~mm}$ hemispherical electron energy analyser (Sphera II, 7 channel detector, ScientaOmicron $\mathrm{GmbH}$ ). The XPS was housed in an ultrahigh vacuum chamber with a base pressure of $10^{-11}$ mbar. XPS data were collected over $\mathrm{Fe}, \mathrm{C}$ and $\mathrm{O}$ core levels at a pass energy of $20 \mathrm{eV}$ using $0.1 \mathrm{eV}$ steps and a dwell time of $0.1 \mathrm{~s}$. The $\mathrm{O} 1 \mathrm{~s}$ core level was fit using symmetric components after subtracting a Shirley background. 


\section{Conclusions}

The electrochemical behavior of mild steel in different $\mathrm{HCO}_{3}{ }^{-}$, $\mathrm{DO}$ concentrations and immersion time was studied, using potentiodynamic polarization and electrochemical impedance spectroscopy. Pitting corrosion depth increases with increasing bicarbonate concentrations. Lowering the amount of dissolved oxygen facilitates passivation, whereas an increase in dissolved oxygen and $\mathrm{HCO}_{3}{ }^{-}$ in bicarbonate/chloride results in a significant increase in the cathodic oxygen reduction process and anodic metal dissolution due to oxidation. The corrosion current density decreases significantly with decreasing DO concentration, dropping from $201.5 \mu \mathrm{A} \cdot \mathrm{cm}^{-2}$ at $4 \mathrm{ppm}$ to $22.3 \mu \mathrm{A} \cdot \mathrm{cm}^{-2}$ at $0.8 \mathrm{ppm}$. A relatively stable oxide films were formed at $\sim 600 \mathrm{mV}_{\mathrm{SCE}}$ at lowered $\mathrm{DO}(1-0.8 \mathrm{ppm})$ concentrations. Immersion time has an important effect: the oxide film thickness increases and the corrosion rate decreases with increasing immersion time. Internal corrosion of mild steel pipelines in high bicarbonate/chloride environment can be minimized when $\mathrm{DO}$ concentration is relatively low at $\mathrm{pH} \geq 8$ and potential $\approx-600 \mathrm{mV}_{\mathrm{SCE}}$. Oxygen is necessary for passive film formation, but can be detrimental to mild steel above the critical level in high bicarbonate/chloride solution under dynamic conditions.

Acknowledgments: This work was funded by the Australian Government and Queensland University of Technology. The authors express their gratitude for the financial support and some characterizations performed at the Central Analytical Research Facility (CARF) operated by the Institute for Future Environments (QUT).

Author Contributions: Geoffrey Will and Willem Dekkers are the supervisory team, both helped in designing the experiment, Jennifer MacLeod analysed the XPS data, Gaius Debi Eyu performed the experiments and the data analyses.

Conflicts of Interest: The authors declare no conflict of interest.

\section{References}

1. King, F. Overview of a Carbon Steel Container Corrosion Model for a Deep Geological Repository in Sedimentary Rock; Nuclear Waste Management Organization Technical Report: Toronto, ON, Canada, 2007.

2. Castro, E.; Vilche, J.; Arvia, A. Iron dissolution and passivation in $\mathrm{K}_{2} \mathrm{CO}_{3} / \mathrm{KHCO}_{3}$ solutions. Rotating ring disc electrode and XPS studies. Corros. Sci. 1991, 32, 37-50.

3. Davies, D.; Burstein, G. The effects of bicarbonate on the corrosion and passivation of iron. Corrosion 1980, 36, 416-422. [CrossRef]

4. Linter, B.; Burstein, G. Reactions of pipeline steels in carbon dioxide solutions. Corros. Sci. 1999, 41, 117-139. [CrossRef]

5. Tan, Y.T.; Wijesinghe, S.L.; Blackwood, D.J. The inhibitive effect of bicarbonate and carbonate ions on carbon steel in simulated concrete pore solution. Corros. Sci. 2014, 88, 152-160. [CrossRef]

6. Moreno, M.; Morris, W.; Alvarez, M.G.; Duffó, G.S. Corrosion of reinforcing steel in simulated concrete pore solutions: Effect of carbonation and chloride content. Corros. Sci. 2004, 46, 2681-2699. [CrossRef]

7. Might, J.; Duquette, D. Stress corrosion cracking of high-purity carbon steel in carbonate solutions. Corrosion 1996, 52, 428-434. [CrossRef]

8. Pilkey, A.; Lambert, S.; Plumtree, A. Stress corrosion cracking of X-60 line pipe steel in a carbonate-bicarbonate solution. Corrosion 1995, 51, 91-96. [CrossRef]

9. Mao, X.; Liu, X.; Revie, R. Pitting corrosion of pipeline steel in dilute bicarbonate solution with chloride ions. Corrosion 1994, 50, 651-657. [CrossRef]

10. Thomas, J.; Davies, J. Influence of hydrogen carbonate and chloride ions on the stability of oxide films on mild steel in near-neutral solutions. Br. Corros. J. 1977, 12, 108-114. [CrossRef]

11. Abdulrahman, A.; Ismail, M.; Hussain, M.S. Inhibition of corrosion of mild steel in hydrochloric acid by Bambusa arundinacea. Int. Rev. Mech. Eng. 2011, 5, 59-63.

12. Lu, Z.; Huang, C.; Huang, D.; Yang, W. Effects of a magnetic field on the anodic dissolution, passivation and transpassivation behaviour of iron in weakly alkaline solutions with or without halides. Corros. Sci. 2006, 48, 3049-3077. [CrossRef]

13. Xue, H.; Cheng, Y. Passivity and pitting corrosion of X80 pipeline steel in carbonate/bicarbonate solution studied by electrochemical measurements. J. Mater. Eng. Perform. 2010, 19, 1311-1317. [CrossRef] 
14. Cáceres, L.; Vargas, T.; Herrera, L. Influence of pitting and iron oxide formation during corrosion of carbon steel in unbuffered $\mathrm{NaCl}$ solutions. Corros. Sci. 2009, 51, 971-978. [CrossRef]

15. Gadala, I.M.; Alfantazi, A. Electrochemical behavior of API-X100 pipeline steel in NS4, near-neutral, and mildly alkaline $\mathrm{pH}$ simulated soil solutions. Corros. Sci. 2014, 82, 45-57. [CrossRef]

16. Kermani, M.; Morshed, A. Carbon dioxide corrosion in oil and gas production-A compendium. Corrosion 2003, 59, 659-683. [CrossRef]

17. Han, J.; Zhang, J.; Carey, J.W. Effect of bicarbonate on corrosion of carbon steel in $\mathrm{CO}_{2}$ saturated brines. Int. J. Greenh. Gas Control 2011, 5, 1680-1683. [CrossRef]

18. Yunovich, M.; Xia, Z.; Szklarska-Smialowska, Z. Factors influencing stress corrosion cracking of carbon steel in diluted bicarbonate environments. Corrosion 1998, 54, 155-161. [CrossRef]

19. Delanty, B.; O’Beirne, J. Major field study compares pipeline SSC with coatings. Oil Gas J. 1992, 90, 39-44.

20. Gedge, G. Corrosion of cast Iron in potable water service. In Proceedings of the Institute of Materials Conference, London, UK, 1993; pp. 18-28.

21. Abdallah, M. Corrosion behaviour of 304 stainless steel in sulphuric acid solutions and its inhibition by some substituted pyrazolones. Mater. Chem. Phys. 2003, 82, 786-792. [CrossRef]

22. Finnegan, T.J.; Corey, R.C. Corrosion of Steel Quantitative Effect of Dissolved Oxygen and carbon Dioxide. Ind. Eng. Chem. 1935, 27, 774-780. [CrossRef]

23. Oldfield, J.; Todd, B. Corrosion considerations in selecting metals for flash chambers. Desalination 1979, 31, 365-383. [CrossRef]

24. Oldfield, J.W.; Todd, B. Technical and economic aspects of stainless steels in MSF desalination plants. Desalination 1999, 124, 75-84. [CrossRef]

25. Beckett, M.; Beckett, M.; Snoeyink, V.; Jim, K.; Sarin, P.; Kriven, W.; Lytle, D.; Clement, J. A pipe loop system for evaluating iron uptake in distribution systems. In Proceedings of the Water Quality Technology Conference, San Diego, CA, USA, 1-4 November 1998.

26. Sarin, P.; Sarin, P.; Bebee, J.; Beckett, M.; Jim, K.; Lytle, D.; Clement, J.; Kriven, W.; Snoeyink, V. Mechanism of release of iron from corroded iron/steel pipes in water distribution systems. In Proceedings of the Annual Technology Confrence, Denver, CO, USA, 11-15 June 2000.

27. Mcneiill, L.S.; Edwards, M. Iron pipe corrosion in distribution systems. Am. Water Works Assoc. 2001, 93, 88-100.

28. Kuch, A. Investigations of the reduction and re-oxidation kinetics of iron (III) oxide scales formed in waters. Corros. Sci. 1988, 28, 221-231. [CrossRef]

29. Baek, W.-C.; Kang, T.; Sohn, H.-J.; Kho, Y.T. In situ surface enhanced Raman spectroscopic study on the effect of dissolved oxygen on the corrosion film on low carbon steel in $0.01 \mathrm{M} \mathrm{NaCl}$ solution. Electrochim. Acta 2001, 46, 2321-2325. [CrossRef]

30. Eliyan, F.F.; Mahdi, E.; Alfantazi, A. Investigating the corrosion of API-X100 pipeline steel in aerated carbonate solutions by electrochemical methods. Int. J. Electrochem. Sci. 2013, 8, 578-590.

31. Eyu, G.D.; Will, G.; Dekkers, W.; Macleod, J. Effect of hydrodynamics and surface roughness on the electrochemical behaviour of carbon steel in CSG produced water. Appl. Surf. Sci. 2015, 357, 506-515. [CrossRef]

32. Popova, A.; Sokolova, E.; Raicheva, S.; Christov, M. AC and DC study of the temperature effect on mild steel corrosion in acid media in the presence of benzimidazole derivatives. Corros. Sci. 2003, 45, 33-58. [CrossRef]

33. Khaled, K.; Hackerman, N. Investigation of the inhibitive effect of ortho-substituted anilines on corrosion of iron in $1 \mathrm{M} \mathrm{HCl}$ solutions. Electrochim. Acta 2003, 48, 2715-2723. [CrossRef]

34. Eliyan, F.F.; Mahdi, E.-S.; Alfantazi, A. Electrochemical evaluation of the corrosion behaviour of API-X100 pipeline steel in aerated bicarbonate solutions. Corros. Sci. 2012, 58, 181-191. [CrossRef]

35. Zhang, L.; Li, X.G.; Du, C.W.; Cheng, Y.F. Corrosion and stress corrosion cracking behavior of X70 pipeline steel in a CO2-containing solution. J. Mater. Eng. Perform. 2009, 18, 319-323. [CrossRef]

36. Park, J.-J.; Pyun, S.-I.; Lee, W.-J.; Kim, H.-P. Effect of bicarbonate ion additives on pitting corrosion of type 316L stainless steel in aqueous $0.5 \mathrm{M}$ sodium chloride solution. Corrosion 1999, 55, 380-387.

37. Ståhl, K.; Nielsen, K.; Jiang, J.; Lebech, B.; Hanson, J.C.; Norby, P.; Lanschot, J.V. On the akaganéite crystal structure, phase transformations and possible role in post-excavational corrosion of iron artifacts. Corros. Sci. 2003, 45, 2563-2575. [CrossRef] 
38. Heuer, J.; Stubbins, J. An XPS characterization of FeCO3 films from CO2 corrosion. Corros. Sci. 1999, 41, 1231-1243. [CrossRef]

39. Grosvenor, A.; Kobe, B.A.; Biesinger, M.C.; Mclntyre, N.S. Investigation of multiplet splitting of Fe 2p XPS spectra and bonding in iron compounds. Surf. Interface Anal. 2004, 36, 1564-1574. [CrossRef]

40. Rowles, M.R.; Madsen, I.C. Whole-pattern profile fitting of powder diffraction data collected in parallel-beam flat-plate asymmetric reflection geometry. J. Appl. Crystallogr. 2010, 43, 632-634. [CrossRef]

41. Toraya, H.; Huang, T.; Wu, Y. Intensity enhancement in asymmetric diffraction with parallel-beam synchrotron radiation. J. Appl. Crystallogr. 1993, 26, 774-777. [CrossRef]

42. Haggerty, R.P.; Sarin, P.; Bérar, J.-F.; Apostolov, Z.D.; Kriven, W.M. Powder diffraction by fixed incident angle reflection using a curved position-sensitive detector. J. Appl. Crystallogr. 2010, 43, 560-569. [CrossRef]

(C) 2016 by the authors; licensee MDPI, Basel, Switzerland. This article is an open access article distributed under the terms and conditions of the Creative Commons Attribution (CC-BY) license (http://creativecommons.org/licenses/by/4.0/). 